\title{
School Leadership Development Process and Its Implementations in Public Secondary Schools of Bale Zone, Oromia Regional State, Ethiopia
}

\author{
Asheber Demie', Ziyn Engidasew², Garkebo Basha3 ${ }^{3}$, Feyera Dinsa Hundessa ${ }^{1}$ \\ ${ }^{1}$ Educational Leadership and Policy Studies, Haramaya University, Haramaya, Ethiopia \\ ${ }^{2}$ Educational Management, Adama Science and Technology University, Adama, Ethiopia \\ ${ }^{3}$ Adult Education and Community Development, Haramaya University, Haramaya, Ethiopia \\ Email: zatsat08@gmail.com, engdasewziyn1970@gmail.com, garadured@gmail.com, feyera2005@yahoo.com
}

How to cite this paper: Demie, A., Engidasew, Z., Basha, G., \& Hundessa, F. D. (2021). School Leadership Development Process and Its Implementations in Public Secondary Schools of Bale Zone, Oromia Regional State, Ethiopia. Creative Education, 12, 2301-2321.

https://doi.org/10.4236/ce.2021.1210174

Received: August 18, 2021

Accepted: October 15, 2021

Published: October 18, 2021

Copyright $\odot 2021$ by author(s) and Scientific Research Publishing Inc. This work is licensed under the Creative Commons Attribution International License (CC BY 4.0).

http://creativecommons.org/licenses/by/4.0/

(c) (i) Open Access

\begin{abstract}
The purpose of the study was to assess School leadership development process and is implementations in Oromia regional state Bale zone public secondary schools. To achieve this purpose, a survey research design, in focus, was used. Both probability and non-probability sampling techniques were used to select participants from various groups. To this effect, total of 16 secondary schools were selected. There are total of 1046 populations from these 367 teachers selected by simple random and 41 school leaders were selected by available sampling techniques. Among 375 questionnaires distributed to secondary schools teacher and school leaders, 346 (92\%) were properly filled and returned for analysis. Quantitative data have been presented via mean standardization and independent sample $t$ test data analysis methods were used. The major findings of the study revealed that the current implementations of school leadership development process in the study area showed that school leadership development implementations has problems specially in selection, recruitment, assignment of school leaders for development before and after development. School leadership development process during implementations mainly dominated by political affiliation and intimacy were seen during school leaders recruitment, selection and assignment in the zone. The researcher recommended that secondary school leaders' selection, recruitment and assignment had better implemented on the basis of clear and well defined criteria. The Education office has to adjust open access and diversified methods to invite potential applicants; they have to give the value to academic qualification merit based during selecting.
\end{abstract}




\section{Keywords}

Implementations, Leadership Selection, Recruitment and Leadership

Profession

\section{Introduction}

School leadership development has become a priority in education policy agenda internationally and nationally. Specific development for school leaders is linked to the evidence that high-quality leadership is vital for school improvement and student outcomes. There is growing recognition that the quality of leaders and leadership is critical, if schools are to produce the best possible outcomes for their learners and their stakeholders (Hallinger and Bryant, 2012). The significance of effective leadership for the successful operation of schools is widely acknowledged in the twenty-first century. The role of school managers in education is crucial, although discredited in the educational hierarchy, for the proper functioning of the schools they run. They are the visionaries, the ones who capture and inspire a vision for the future of their school units and together with their collaborators the teachers are called to realize it. At the same time, they are the ones responsible for the proper functioning of the school unit, the educators who draw the guidelines, the animating spirits of teachers and students, the coordinators of the efforts, the people who solve any problem that arises in the school unit, the bureaucrats who represent the central government, the financially accountable for the proper management of the unit's resources, the innovation rapporteurs, those responsible for the personal and professional development of teachers. Finally, they are the connecting links of all the groups that make up the school unit, the collaborators of all, but also the final liable for any negligence or unfortunate incident that arises in the educational unit they lead. Therefore, their role has a multidimensional character and concerns not only their direct collaborators, but also reflects on a wider part of society.

More governments are realizing that their main assets are their people and that remaining or becoming competitive depends increasingly on the development of a highly skilled workforce. This requires trained and committed leaders but they in turn need the leadership of highly effective leaders with the support of other senior and middle managers (Bush, 2009). In order to build school leadership capacity is a crucial component of educational change while the development and preparation of school leaders is widely supported (Bush, Kiggundu, and Moorosi, 2011). Nowadays, the important concept of school leadership in order to get excellent achievement is widely accepted and acknowledged. Higher achievement for every student and better academic success can be associated directly to school leadership (Hoy and Miskel, 2005). It is a logical thing to invest heavily in school leadership development in the anticipation of improved performance and outcomes which is practiced by many countries (Bush et al., 
2011).

Interest in effective leadership development has been coming to enhancement in both profitable and non-profitable organizations (Avolio, 2004; Avolio and Gardner, 2005; Avolio et al., 2010; Bolden, 2006; Day, 2001). On the other hand, the literature on leadership development and its impact has been noticed little and most of the leadership development studies have less been noticed to be empirical (Collins, 2002).

The Education and training policy document of Ethiopia Ministry of Education also gives payable consideration that school leaders and other educational personnel will be organized, on the basis of professional principles, including professional code of ethics, professional development and overall rights and duties. The policy stated that educational leaders be professional. School leadership is a profession that requires special development for leading educational organization and schools (MoE, 1994).

Furthermore, the Ethiopian Education development Road Map MoE (2019) revised document presented for discussion also gives attention for school leaders' development. The capacity to plan, manage and monitor the education system demands knowledge and skill in collecting, processing, analyzing and managing educational information at all levels of the system. Weak capacities in strategic planning and leadership, implementation, monitoring and evaluation hinder the education system. The education leadership capacity is generally weak, limited leaders' capacities of educational authorities at the regional, zonal, Woreda and school levels. The National Policy on appointment, assignment and development of School leaders says that school leaders have to be developed before and after appointment to school leadership. They can only become school leaders if they have a Credential in school leadership respectively.

The main aim of school leadership development to respond for the growing number to schools Ethiopia in general and specifically to Bale Zone that needs professionals qualified in school leadership. In some schools, there are two or more vice school leaders depending on the number of teachers and students; so having qualified and developed school leaders were the essential representative for schools increased year to year in all levels. However, the reality of Bale Zone contradicts. The number of school leader developed in leadership profession in Bale Zone is still few in numbers, lacks development process, below standards set by MoE, nominated without clear criteria for development and unqualified secondary school leaders below standards were selected and assigned for the position.

As the three consecutive years of zonal education bureau data indicates, in years 2016, the number of secondary school leaders with the standard of secondary schools was 9 from total of 54 secondary school leaders. In 2017, out of 57 secondary schools' leaders those at the standards were 13 in number, in 2018 from a total 60 (sixty) secondary schools the numbers of school leaders those pass through school leadership development as the standard of MoE were 18. 
This indicates that secondary school leaders who developed in school leadership development process in different years were insufficient in number and the implementations of secondary school leadership development process of recruitment, selection and assignment for development were disagreeing with the standard set by ministry of education. In addition, school leaders who were qualified and developed leave the school leadership positions after serving for few years, those selected were not competence based in school leadership development process and those developed with school leadership were turn over the positions of school leaders Bale Zone Education office of 2018 report.

To overcome the gap identified school leadership development process and its implementations at secondary schools for professional leadership is the rational that initiated the researcher to undertake this Study. This study is therefore, aimed at assessing of school leadership development process and its implementations in secondary schools of Bale Zone

\section{Statement of the Problem}

Leadership development is a critical determinant of organizational performance across organizations, including schools. In this regard, increasing attention is being paid internationally to develop high-quality school leadership development process and implementation is necessary. School leaders are enamored by their potential to equip potential leaders for their work by emphasizing instructional and organizational leadership (Bush and Jackson, 2002). Following general agreement of the importance of meaningful school leader development process to successful school leadership, research has documented indicators and features of high-quality leadership development process were the vital one especially for leading schools (Barber, Whelan and Clark, 2010).

MoE (2013) gave concern to alleviate school leaders' profession by giving great attention to recent innovation, like professional development and Teacher development, but in light of the indicated facts school leadership development process lacks attention as required and faced challenges. Some of the challenges in secondary schools of Bale Zone were lack of development for secondary schools, number of qualified school leaders turn over the positions.

As a rational for launching the new school leaders' development in the national curriculum framework of school leadership development process, it was further demonstrated that secondary school leaders were to align the recently developed standards of school leaders with the new development process were additional reasons to launch school leadership development.

A study conducted at Ambo University Ethiopia shows that the historical development of the Ethiopian school leadership development process in different stages were examined the development of the school leadership of a nation that lasted over a century has many challenges from different angles. This study identified the ups and down of school leadership development process starting from evolution to current time was political command. Unfortunately, those de- 
cisions didn't involve educational stakeholders and most often, it didn't incorporate the will and concerns of the leaders'. Furthermore, evolution of the school leadership was changeable in that it fluctuated back and forth rather than consistently advancing forward. Hence, school leadership development of the nation could not contribute what it must contribute to the Ethiopian school leadership in development (Tesfaye, 2018).

Other explanatory qualitative study conduct by Tesfaye at Ambo University, 'Selection and Preparation of School Leaders' also identified about the process of selection for development of school leaders gaps. The finding shows that selection of competent school leaders for development lacks attention. The criteria and procedures of selection need revision. However, the study did not touches ones the other segment of school leadership development implementation in secondary schools but concerned only with primary school levels in which the selection not to development process and implementations have not been touched on (Tesfaye, 2019).

In fact there were many educational achievements have been enumerated in the country: for instances, leadership development education and attempts made to optimize leadership development are achievements registered since the introduction of General Education Quality Program (MoE, 2010). However, beside the achievements, there are still many problems entitled with the school leadership development process which needs future cooperative and sustainable effort to resolve the problems. In line with this, Ministry of Education identified problems such as limited capacity of school leaders at secondary school level and shortage of development for their skills and capacity problems. Such gaps, initiated. The Ethiopian government attempted to give emphasis to develop and strengthen school leadership capacity in ESDP by designing new and organized school leadership development. However, in many secondary schools, school leaders are being selected and assigned at the leadership capacity without having leadership qualification, inefficient skills of leadership capacity without development in school leadership are still challenges that need solution (MOE, 2013).

Other study conducted by Etsegenet (2019) "Leaders Development Practices and Challenges in Government Secondary Schools in Yeka Sub City" identifies that leaders' development practices were guided through school policy and plan; however, managerial attitudinal problem and scarcity of resources are hindering the effectiveness and efficiency of the leaders' development practice. This study focuses at practices and challenges of leaders' development at school level and the participant in which the study ignored the inclusion of the school leaders at woredas and zonale level. In addition the study did not touch on the process and implementation of school leadership development due to the delimitation of the study. This study, however, is different from Etsegenet's study in those participants of the study and the study area varies in addition to the concerns with school leadership development process and its implementations in secondary schools of Bale Zone. 
MoE (2010) in ESDPIV suggests that a special leadership development has been initiated to build the capacity of school leaders towards planning and managing school activities with the introduction of ESDPs, in which leadership and administration (LAM) has been introduced with due attention to general education quality improvement programs GEQIP (MoE, 2008). However, the practices of school leadership development to be compulsory are still more confined to nomination from among teachers. The nomination of school leaders usually takes place at Zonale or Woreda levels. which resulted into the selection, recruitment and assignment of, the majority of secondary school leaders' below the standard set in the ESDP V though the Ministry of Education suggests the selection, recruitment and assignment of leadership from that graduates of the first degree for primary schools while second degree holders meant for secondary school leadership with identified criteria (MoE, 2014). However the Ministry of Education identified pre conditions for the positions the implementations were far apart from the suggested reality.

Another qualitative study conducted by Abebe et al., (2009) in Gambela Region shows that majority of the school leaders become school leaders without the necessary development in school leadership. Most of the school leaders required development both in teaching and school leadership. The study indicated the strategies' of enhancing school leadership was insufficient, with gaps in recruitment and development of school leaders has gaps. On the other side it focuses at both secondary and primary schools. The study method and the variables in study area and time of study were differed from the current study.

The key challenges of secondary school leaders of today are lack of development of school leaders and clear criteria of selection, recruitment and assignment. Regarding this, Workineh (2012) described as: Until recently, school leader's development was not given attention in education practice and academic research about school leadership development in Ethiopia. Instead policy documents tend to focus mainly on access and equity.

So these all gaps greatly initiate the researcher to assess school leadership development process and its implementations in public secondary schools of Bale Zone, the study focus on the following basic question.

1) How school leadership development implementations in Oromia Regional State, Bale Zone public secondary schools?

2) What look like school leadership (selection, recruitment and assignment) for leadership development in Oromia Regional State, Bale Zone public secondary schools?

\section{Research Methods}

\subsection{Research Design}

Quantitative research method and descriptive survey design was employed to study this problem. As Best and Kahn (2003) descriptive survey designs help to gather data from large number of samples within limited period of time. More- 
over, descriptive survey method was typically used to examine and describe problems and determine the distribution of variables that are difficult to observe.

\subsection{Sources of Data}

The sources of data for the study were primary and secondary sources of data were employed. The primary data were obtained from secondary school teachers, secondary school leaders (principals and vice principals) through questionnaires and secondary data sources were obtained from documents like reports and related credentials.

\subsection{Sampling Techniques and Sample Size}

This study was conducted in Bale Zone some selected public secondary schools. were selected by stratified sampling method from this three stratas 16 secondary schools were sampled by simple random techniques 367 teachers were selected by simple random sampling techniques' 41 school leaders (principals and vice principals) by available sampling technique since they were important to pertinent data (Gay, Geoffrey and Airasian, 2012). Among population of 1046 teachers and secondary school leaders in 16 secondary schools, 35\% (375) of teachers and school leaders were selected for the representativeness of the population. Based on sample size determination table calculated by Cohen, Manion and Morrison (2007) and the desire margin of error, the confidence level, and the anticipated response rate, the researcher used 20 to 30 percent suggested by (Mugenda \& Mugenda, 2003).

\subsection{Method of Data Collection}

Questionnaires were the main data gathering instrument used for the study. Selfdeveloped questioners items were administered for secondary school teachers and school leaders. Both closed and open-ended questions were used. The items are 5 Point Likert-scales in nature (ranging from 1 to 5). The questionnaire was designed in a way that respondents would give their background information as well as the data which the research questions sought to address. The first part of the questionnaire consisted of five variables that focused on background information about respondents. The second part consisted of 18 items concerning about school leadership development implementations items (school leadership selection, recruitment, assignment and commitment of school leaders) for leadership development in public secondary schools.

\subsection{Method of Data Analysis}

After collecting and coordinating primary data, were checked through data checking and cleaning of the filled questionnaire to identify valid responses and to remove the invalid ones. After doing so, then, the data collected through questionnaire were analyzed quantitatively using descriptive statistics such as frequency, percentage, mean, and standard deviation. Hence, in order to analyze 
and interpret the data collected about the practices, perceptions and implementations of school leadership development activities of school leadership selection, recruitment, assignment and commitment of school leaders for leadership development. Descriptive statistics such as, frequency, mean scores and inferential statistics independent sample t test were used.

\section{Results and Discussion of the Study}

As can be seen Table 1 indicates that; 217 (63\%) of teachers and $36(11 \%)$ of the school leaders were males. While 91 (26\%) teachers and none of the school leaders were females. The absence of female school leaders might have negative implication in the school leadership development process and its implementations of gender sensitive. In other cases of the groups of respondents, the proportion of males exceeds that of the females. This contradicts the view in the MoE (1994) states that the presence of more female participation in the educational leadership and school population would encourage females' participation in education in addition to providing positive role models to young girls, particularly in rural area.

As can be seen from the table above, 1 (3\%) of the teachers are in the age range less than 25 years, whereas, the $71(21 \%)$ teachers and $5(1 \%)$ of the school leaders are in the range of $26-30$ and $144(42 \%)$ teachers 19 (5\%) of the school leaders age in range of 31 - 40 years old. Similarly, 59 (17\%) of the teachers and 11 (3\%) of school leaders were found in age interval of $41-50$. In other hand 25 (7\%) of teachers and 3 (1\%) of school leaders are above 50 years of age. From this we conclude that majority of teachers and school leaders are in the age of 31 - 40, few of teachers and school leaders were nearly in age of retirement and in the age of less experienced to involve in leadership development process. This has side effect in leadership development process and its implementations because of

Table 1. Background information of the respondents.

\begin{tabular}{|c|c|c|c|c|c|}
\hline \multirow{3}{*}{ Variables } & \multirow{3}{*}{ Categories } & \multicolumn{4}{|c|}{ Respondents $(\mathrm{N}=346)$} \\
\hline & & \multicolumn{2}{|c|}{ Teacher } & \multicolumn{2}{|c|}{ School leader } \\
\hline & & № & $\%$ & № & $\%$ \\
\hline \multirow{3}{*}{ Sex } & Male & 217 & 63 & 38 & 11 \\
\hline & Female & 91 & 26 & - & - \\
\hline & Total & 308 & 89 & 38 & 11 \\
\hline \multirow{6}{*}{ Age (in years) } & $<25$ & 9 & 3 & - & - \\
\hline & $26-30$ & 71 & 21 & 5 & 1 \\
\hline & $31-40$ & 144 & 42 & 19 & 5 \\
\hline & $41-50$ & 59 & 17 & 11 & 3 \\
\hline & $>50$ & 25 & 7 & 3 & 1 \\
\hline & Total & 308 & 90 & 38 & 10 \\
\hline
\end{tabular}


age and experiences lack of interest to participate in leadership development and their commitment were less motivated.

As it can be seen in the Table 2, 66 (19\%) of teachers and 7 (2\%) of school leaders had a second degree in different fields of specialization. 23 (7\%) of teachers and $10(3 \%)$ school leaders were MA in educational planning and Management. Majority of teacher 219 (63\%) of them and 21 (6\%) of school leaders had BA/BSc, were qualified with the first degree. As far as qualification of the school leaders concerned, majority of them, were first degree holders. One contradicting issue here is the fact that almost all or at least majority of school leaders serving in the secondary schools in the zone are not qualified for the level of their assignment for leading. The number of school leaders those leading secondary schools were below the standards set by the ministry of education, The other points need concern is teachers those had second degree in Educational planning and Management were assign to teach with their first degree after they leave the position with different cases.

In terms of educational level majority of the schools leaders have first degree. However, this contradicts with the criteria indicated in the blue print of teachers'

Table 2. Respondents by educational qualification.

\begin{tabular}{|c|c|c|c|c|c|}
\hline \multirow{3}{*}{ Variables } & \multirow{3}{*}{ Categories } & \multicolumn{4}{|c|}{ Respondents $(\mathrm{N}=346)$} \\
\hline & & \multicolumn{2}{|c|}{ Teacher } & \multicolumn{2}{|c|}{ School leader } \\
\hline & & No. & $\%$ & No. & $\%$ \\
\hline \multirow{6}{*}{ Qualification } & $\mathrm{MA} / \mathrm{MSc} / \mathrm{MED}$ & 66 & 19 & 7 & 2 \\
\hline & MA/EDPM & 23 & 7 & 10 & 3 \\
\hline & $\mathrm{BSc} / \mathrm{BA} / \mathrm{BED}$ & 219 & 63 & 21 & 6 \\
\hline & $12+2 / 10+3$ & - & - & - & - \\
\hline & Certificate/Level & - & - & - & - \\
\hline & Total & 308 & 89 & 38 & 11 \\
\hline \multirow{6}{*}{ Specialization } & Natural science & 165 & 48 & 12 & 4 \\
\hline & Social science & 128 & 37 & 18 & 5 \\
\hline & EDPM & 3 & 1 & - & - \\
\hline & School leadership & 12 & 4 & 8 & 2 \\
\hline & Others & - & - & - & - \\
\hline & Total & 308 & 89 & 38 & 11 \\
\hline \multirow{6}{*}{ Work experiences } & $<3$ & - & - & - & - \\
\hline & $4-6$ & 13 & 4 & - & - \\
\hline & $7-9$ & 29 & 8 & - & - \\
\hline & $10-12$ & 69 & 20 & 6 & 2 \\
\hline & $>12$ & 197 & 57 & 32 & 9 \\
\hline & Total & 308 & 89 & 38 & 11 \\
\hline
\end{tabular}


development program (MoE, 2007). In the document it is stipulated that academic qualification required for the secondary school leaders is a master's degree. This indicates that with regard to educational level, majority of the secondary schools leaders were leaded by less qualified individuals. Thus, it is possible to judge that majority of school leaders in the study were professionally unqualified. The qualification of school leaders and related professional skill and knowledge was against the intended plan of Ethiopian Ministry of education. It was against what was stipulated in the blue print that claims, "secondary school leaders need to have second degree in Educational leadership". Whereas, almost Majority school leaders have first degree in subject area. Here, lack of professionally capable leaders was still found to be greatly influencing performances of schools in general and effectiveness of the leadership of the leaders in particular. Therefore, it is possible to conclude that effectiveness of the leadership of leaders is highly influenced by the miss match between their qualification and educational levels that were rated to be below the standard set by Ethiopian Ministry of Education.

As it can be seen in the table above, as to the field of specialization of teacher respondents, majority of the teachers, $165(48 \%)$ of them and 12 (were from natural sciences specializing in natural sciences. From these data, with exception of those lacking fields of specialization in subjects rather than school leadership, it can be said that school leadership has been offered mainly by school leaders of inappropriate fields of specialization as per the policy direction of the country. This also contravenes what is stipulated in the blue print of teachers' development program (MoE, 2007) that the document states, the school leaders need to have adequate knowledge, skills and attitude in the area of educational leadership. This might indicate that the leaders were made to lead the school without a clear understanding of theories and principles of educational leadership. The other thing that one can conclude from this is some teachers specialized with Educational planning and Management and school leadership were assigned to teach in their first degree after they have been involved in leadership development. This shows there is turnover of school leaders because of different reasons.

As Table 2 shows that, 13 (4\%) of teachers and none of school leaders have served for over 4 - 6 years; whereas some 29 (8\%) of teachers and none of school leaders serve 7 - 9 years old. 69 (30\%) teachers and $6(2 \%)$ of school leaders have services of $10-12$, Majority of teachers 197 (57\% and 32\%) of school leaders have served more than twelve years. Regarding to the work experiences of the school leaders; majority of them have long experiences. From the data follows that all of the respondents have adequate year's exposure and rich experiences in teaching, hence they can provide information regarding the implementations of school leadership development.

As indicated above in Table 3 item 1 mean value of the opinions of the participants were calculated and found to be high; that is 3.67 at standard deviation of 0.096 , which is above the average mean value, 3, showing that most school leaders are selected for school leadership development with personal relationship 
Table 3. School leader's selection for leadership development.

\begin{tabular}{|c|c|c|c|c|c|c|}
\hline Items & $\bar{X}_{R}$ & $\bar{X}_{U}$ & $\bar{X}_{T}$ & Std.Dv & t-value & $P$-value \\
\hline $\begin{array}{l}\text { 1) There are clear set selection criteria to } \\
\text { involve in school leaders' development. }\end{array}$ & 3.77 & 3.56 & 3.67 & 0.097 & 1.539 & 0.125 \\
\hline 2) Most school leaders are selected for school & & & & & & \\
\hline $\begin{array}{l}\text { leadership development with personal } \\
\text { relationship. }\end{array}$ & 3.58 & 3.11 & 3.35 & 0.087 & 3.561 & 0.000 \\
\hline \multicolumn{7}{|l|}{ 3) Selection of school leaders for school } \\
\hline $\begin{array}{l}\text { leadership development is affiliated by } \\
\text { political loyalty. }\end{array}$ & 4.04 & 3.52 & 3.78 & 0.086 & 4.347 & 0.000 \\
\hline $\begin{array}{l}\text { 4) Education office gives equal opportunities } \\
\text { for all teachers' selection to involve in school } \\
\text { leadership development. }\end{array}$ & 3.89 & 3.81 & 3.85 & 0.080 & 0.680 & 0.497 \\
\hline Total & & & 3.66 & 0.088 & & \\
\hline
\end{tabular}

Keys: Df-Degree Freedom; $P<0.05 ; \quad \bar{X}_{R}$-Rural mean, $\bar{X}_{U}$-Urban mean, $\bar{X}_{T}-$ Total mean.

respectively on implementations. This indicates that there are no clear set selection criteria to involve in school leaders' development.

Independent sample t-test indicated that though there were mean differences between the two groups of respondents, statistically insignificant difference in their practices in the item about School leadership development helps school leaders to facilitate vision of learning in the school because the $p$-value greater than $0.05(p=0.123, t=-1.539)$. The result reveals that there is insignificant difference between the rural and urban regarding their opinion. This shows selection criteria of school leaders set were strictly followed the criteria set by the country ministry of education.

The arithmetic mean value Table 3 items 2 the opinions of the participants were calculated and found to be high; that is 3.35 at standard deviation of 0.087 , which is above the average mean value, 3 , showing that most school leaders are selected for school leadership development with personal relationship. Independent sample t-test indicated that though there were mean differences between the two groups of respondents, statistically significant difference in their practices in the item about School leadership development helps school leaders to facilitate vision of learning in the school because the $p$-value less than 0.05 ( $p=$ $0.000, t=-3.561)$. The result reveals that there is significant difference between the rural and urban regarding their perception.

The mean value of Table 3 items of 3 indicates their perceptions were calculated and found to be high; that is 3.78 at standard deviation of 0.086 , which is above the average mean value, 3 showing that selection of school leaders for school leadership development is affiliated by political loyalty. The Independent sample t-test value indicated that though there were mean differences between the two groups of respondents, statistically insignificant difference in their perceptions in the item about school leadership development provides school leaders with the competences that help them to lead learning and teaching because 
the $p$-value greater than $0.05(p=-0.000, \mathrm{t}=-0.4 .347)$. The result reveals that there is significant difference between the rural and urban regarding their perception of about selection of school leaders for school leadership development is affiliated by political loyalty

The arithmetic mean of Table 3 item 4 on the opinions of the participants were calculated and found to be high; that is 3.85 at standard deviation of 0.080 , which is above the average mean value, 3 which indicates education office cannot gives equal opportunities for all teachers' selection to involve in school leadership development. The independent sample $t$ test result reveled that there is a statistical insignificant difference against rural and urban about implementation potential teachers are recruited for school leadership development with clearly identified, transparent, involve all stakeholders since the $p$-value greater than $0.05(p=0.497, \mathrm{t}=-0.680)$. This shows biased opportunities for all teachers' selection to involve in school leadership development.

Following a change of government in 1991, Ethiopia has been undertaking major reforms in its educational system. The education reform and policy in Ethiopia has developed different criteria and process of selection and placement of school leadership. The policy instructs to select and assign the most qualified leadership to the position. Its major focus is making educational leadership professionalize. The policy states that educational leadership practices shall be professional, democratic and efficient (TGE, 1994). However, most of the leadership did not have the required qualification for secondary school leadership and they did not get educational leadership development.

The mean value of the opinions of the participants in Table 4 of item 1 were calculated and found to be high; that is 3.82 at standard deviation of 1.159, which is above the average mean value, 3 . In other side the sample $t$ test value results revealed that there is statistical insignificant difference against rural and urban on perceptions of recruitment of school leaders has impact on school leadership development Since the $p$-value greater that $p>0.05(p=0.99, \mathrm{t}=-0.002)$. The studied variables of school leadership recruitment perceptions against rural and urban were showed insignificant difference $(P>0.05)$. As one concludes from the finding recruitment of school leadership has great impact on leadership development.

The arithmetic mean on the opinions of the participants Table 4 of item 2 were calculated and found to be high; that is 3.29 at standard deviation of 1.087, which is above the average mean value, 3 which indicates there is no clear identified transparent involve of stakeholders for leadership development implementations. The independent sample $t$ test result reveled that there is a statistical significant difference against rural and urban about implementation potential teachers are recruited for school. Leadership development with clearly identified, transparent, involve all stakeholders since the $p$-value less than $0.05(p=0.005, \mathrm{t}$ $=-2.826)$. This shows potential teachers are not recruited for school leadership development with clearly identified, transparent, involve all stakeholders. 
Table 4. Recruitment of school leaders and leadership development.

\begin{tabular}{|c|c|c|c|c|c|c|}
\hline Items & $\bar{X}_{R}$ & $\bar{X}_{U}$ & $\bar{X}_{T}$ & Std.Dv & t-value & $P$-value \\
\hline $\begin{array}{l}\text { 1) Recruitment of school leaders has impact } \\
\text { on school leadership development. }\end{array}$ & 3.82 & 3.81 & 3.82 & 1.159 & 0.002 & 0.99 \\
\hline $\begin{array}{l}\text { 2) Potential school leader are recruited with } \\
\text { clearly identified, transparent, involve all } \\
\text { stakeholders. }\end{array}$ & 3.47 & 3.10 & 3.29 & 1.087 & 2.826 & 0.005 \\
\hline $\begin{array}{l}\text { 3) There is unclear varying, recruitment } \\
\text { procedure of school leaders for school } \\
\text { leadership development. }\end{array}$ & 4.03 & 3.43 & 3.73 & 1.207 & 4.532 & 0.000 \\
\hline $\begin{array}{l}\text { 4) Number of qualified candidates, who } \\
\text { apply for school leadership positions, is } \\
\text { decreased year to year. } \\
\text { Total }\end{array}$ & 3.93 & 3.89 & 3.69 & 1.096 & 0.404 & 0.686 \\
\hline
\end{tabular}

The mean on the opinions of the participants Table 4 of item 3 were calculated and found to be high; that is 3.73 at standard deviation of 1.207 , which is above the average mean value, 3 which indicates there is unclear varying, recruitment procedure of school leaders for school leadership development implementations. In line with this, the $t$ sample two test results revealed that there is a statistical significant difference against rural and urban on the implementations since the $p$-value less than $0.05(p=0.000, \mathrm{t}=-4.532)$. Moreover, the Studied variables of school leadership development implementations against rural and urban were showed significant difference $(p<0.05)$. One can conclude from this there is unclear varying, recruitment procedure of school leaders for school leadership development.

The mean value of the opinions of the participants Table 4 of item 4 were calculated and found to be high; that is 3.92 at standard deviation of 0.932 , which is above the average mean value, 3 which indicates number of qualified candidates, who apply for school leadership positions is decreased year to year. The independent sample $t$ test result reveled that there is a statistical insignificant difference against rural and urban about implementation Number of qualified candidates, who apply for school leadership positions is decreased year to year since the $p>0.05(p=0.686, \mathrm{t}=-0.404)$. This shows number of qualified candidates, who apply for school leadership positions are decreased year to year. Heavy workload, disproportionate salaries, and lack of sufficient development seem to be the most prevalent concerns regarding the working conditions of school leaders. This has led to increasing unattractiveness of the school leadership position, thus making it difficult to attract sufficient candidates to fill advertised posts.

The mean on the opinions of the participants Table 5 item 1 were calculated and found to be high that is 3.59 at standard deviation of 1.22, which is above the average mean value, 3 which nomination or assignment of new school leaders in secondary schools is not based on school leadership development process. 
Table 5. Assignment of school leaders and leadership development.

\begin{tabular}{|c|c|c|c|c|c|c|}
\hline Items & $\bar{X}_{R}$ & $\bar{X}_{U}$ & $\bar{X}_{T}$ & Std.Dv & t-value & $P$-value \\
\hline $\begin{array}{l}\text { 1) Nomination or assignment of new school } \\
\text { leaders in secondary schools is based on } \\
\text { school leadership development process. }\end{array}$ & 3.84 & 3.34 & 3.59 & 1.222 & 3.546 & 0.000 \\
\hline $\begin{array}{l}\text { 2) Assignments to school leadership } \\
\text { positions based on competencies. }\end{array}$ & 3.42 & 3.00 & 3.21 & 1.248 & 2.975 & 0.003 \\
\hline $\begin{array}{l}\text { 3) Appointments to school leadership based } \\
\text { on intimacy. }\end{array}$ & 3.95 & 3.20 & 3.58 & 1.148 & 5.809 & 0.000 \\
\hline $\begin{array}{l}\text { 4) Teaching experience is significantly } \\
\text { important for participating in leadership }\end{array}$ & 3.95 & 3.25 & 3.60 & 1.152 & 5.486 & 0.000 \\
\hline $\begin{array}{l}\text { 5) Political interference eroded professional } \\
\text { autonomy of school leaders in participating } \\
\text { leadership development. }\end{array}$ & 3.53 & 3.07 & 3.30 & 1.289 & 2.909 & 0.004 \\
\hline Total & & & 3.46 & 1.211 & & \\
\hline
\end{tabular}

In line with this, the $t$ sample two test results revealed that there is a statistical significant difference against rural and urban on the nomination or assignment of new school leaders in secondary schools is based on school leadership development process since the $p$-value less than $0.05(p=0.000, \mathrm{t}=-3.546$.

Moreover, the Studied variables of school leadership development assignment during implementations against rural and urban were showed significant difference $(p<0.05)$. From this there is nomination or assignment of new school leaders in secondary schools without involving in school leadership development process. But in most developed world countries like America, England, Sweden and Australia, development of school leaders is formally institutionalized with colleges offering development for school leaders before and after appointment to school leadership. Development of school leaders is also well structured and systematic in the sense that aspiring school leaders are prepared for school leadership before appointment and then continuously developed after appointment to enhance performance of their duties (Fink, 2005). Development of school leaders in these contexts is mandatory and a requirement for anybody wishing to be school leaders.

The mean value of the opinions of the participants were calculated and found in Table 5 of item 2 that is 3.21 at standard deviation of 1.248 , which is above the average mean value, 3 which indicates number of qualified candidates, who apply for school leadership positions is decreased year to year. The independent sample $t$ test result revealed that there is a statistical significant difference against rural and urban about assignments to school leadership positions before school leadership development are based on competencies since the $p<0.05$ ( $p=2.975$, $\mathrm{t}=-0.003)$. This shows assignments to school leadership positions before school leadership development instead of competencies based on different issues.

The arithmetic mean value of the opinions of the participants Table 5 of item 3 were calculated and found to be high that is 3.58 at standard deviation of 1.148 
which is above the average mean value, 3, showing that appointments to school leadership positions after involving in school leadership development are based on intimacy. The Independent sample t-test value indicated that though there were mean differences between the two groups of respondents, statistically significant difference in their perceptions in the item about appointments to school leadership positions after involving in school leadership development are based on intimacy because the $p$-value greater than $0.05(p=-0.000, t=5.809)$.

The mean on the opinions of the participants were calculated and found Table 5 of item 4 is 3.60 at standard deviation of 1.152, which is above the average mean value, 3 which indicates teaching experience is significantly important for participating in leadership development. In line with this, the $t$ sample two test results revealed that there is a statistical significant difference against rural and urban on the implementations since the $p$-value less than $0.05(p=0.000, \mathrm{t}=$ 5.486). Moreover, the Studied variables of school leadership development implementations against rural and urban were showed significant difference $(\mathrm{p}<$ 0.05).

The assumption made is that if they are a good teacher they will be a good principal (Bush and Oduro, 2006). One can conclude from this teaching experience is significantly important for participating in leadership development process. In general, combining the teaching profession is essential qualifications for school leaders. Firstly, a leadership qualification provides school leaders with the necessary tools to steer the school towards its aims. Secondly, the teaching qualification and experience ensure that a school leader has a solid foundation in, and knowledge of, the school system and pedagogy.

The mean value of the opinions of the participants were calculated and found in Table 5 of item 5 is 3.30 at standard deviation of 1.289 , which is above the average mean value, 3 which indicates political interference eroded professional autonomy of school leaders in participating leadership development.

The independent sample $t$ test result reveled that there is a statistical significant difference against rural and urban about assignments to school leadership positions before school leadership development are based on competencies since the $p<0.05$ ( $p=2.999$., $\mathrm{t}=-0.004)$. This shows political interference eroded professional autonomy of school leaders for participating in leadership development.

As the findings reveals in most cases during assignment of school leaders for leadership development political affiliation is major dominated in case of this potential candidate those apply for leadership development and positions were decreased year to year. As the result shows access for school leadership development for school leaders decrease year to year and very few in number, in other side those developed with leadership profession leave the position by different external and internal challenges forced to teach below their the standard.

In a study of 1400 primary and secondary school teachers, principals and deputy principals in Australian state of Victoria in 2000 found that 88 per cent 
had no intention of becoming principals. Any shortage may be made to appear worst where there are high mobility rates. Williams (2001) has found that in Ontario, Canada, close to 75 per cent of principals and over 40 per cent of vice principals expect to retire by the year 2007. The high level of vice principal retirements raised the issue of the quality or depth of the future applicant pool for principal positions.

The mean value of the opinions of the participants Table 6 of item 1 were calculated and found to be low; that is 2.53 at standard deviation of 1.239 , which is below the average mean value, 3 which indicates commitment and motivation of school leaders in participating in school leadership development is less, the independent sample $t$ test revealed that there is statistical insignificant difference against rural and urban about commitment of school leaders in participating in school leadership development is less since the $p>0.05(p=0.769, \mathrm{t}=-0.269)$. This shows commitment of school leaders in participating in school leadership development is least time to time.

More recently in Australia, D'Arbon et al.'s (2001) study of why teachers would not apply for school leadership in Catholic schools in the state of New South Wales found that the highest ranking disincentive to be the impact the job would have on the person's family and personal life. The second highest ranked factor was an unsupportive external environment. Their study also confirmed results from other studies that teachers are content with their current role, do not see adequate remuneration for the increase in responsibility and workload and perceive that the selection process is too complex and intrusive. Teachers in the state of Victoria were found to be steering clear of the school leadership because of the perception that the job is too stressful, demanding and unrewarding. Stress and long work hours were seen as the key turn-offs.

Table 6. Commitment of school leaders for school leadership.

\begin{tabular}{|c|c|c|c|c|c|c|}
\hline Items & $\bar{X}_{R}$ & $\bar{X}_{U}$ & $\bar{X}_{T}$ & Std.Dv & t-value & $P$-value \\
\hline $\begin{array}{l}\text { 1) Commitment of School leaders in } \\
\text { participating in school leadership } \\
\text { development is high. }\end{array}$ & 2.55 & 2.51 & 2.53 & 1.239 & 0.294 & 0.769 \\
\hline $\begin{array}{l}\text { 2) There is an attracting condition for } \\
\text { participating in school leadership } \\
\text { development. }\end{array}$ & 2.45 & 2.50 & 2.48 & 1.280 & -0.375 & 0.708 \\
\hline $\begin{array}{l}\text { 3) A school leader salary attracts potential } \\
\text { candidates involving in school leadership } \\
\text { development. }\end{array}$ & 2.69 & 2.72 & 2.71 & 1.249 & -0.202 & 0.840 \\
\hline $\begin{array}{l}\text { 4) School leadership is an attractive } \\
\text { profession, for which many teachers are } \\
\text { applying. }\end{array}$ & 2.28 & 2.17 & 2.23 & 1.159 & 0.826 & 0.409 \\
\hline $\begin{array}{l}\text { 5) Serving as a school leader motivate } \\
\text { school leaders for involving in school } \\
\text { leadership development. }\end{array}$ & 2.39 & 2.44 & 2.42 & 1.174 & -0.425 & 0.671 \\
\hline Total & & & 2.47 & 1.220 & & \\
\hline
\end{tabular}


The mean value of the opinions of the participants Table 6 items 2 were calculated and found to be low; that is 2.48 at standard deviation of 1.280 , which is below the average mean value, 3 which shows that there is no attracting condition for participating in school leadership development.

The independent sample $t$ test result reveled that there is a statistical insignificant difference against rural and urban about advantage of school leadership development for school to focus on building interpersonal relationships. Since the $p>0.05$ ( $p=0.708, \mathrm{t}=-0.375)$. This shows an attracting condition for participating in school leadership development has not got attention at different levels.

Williams (2001) has found that in Ontario, Canada, close to 75 per cent of principals and over 40 per cent of vice principals expect to retire by the year 2007. The high level of vice principal retirements raised the issue of the quality or depth of the future applicant pool for principal positions.

The mean value of the opinions of the participants Table 6 item 3 were calculated and found to be low; that is 2.71 at standard deviation of 1.249 , which is below the average mean value, 3 which a school leader salary did not attracts potential candidates involving in school leadership development process.

The independent sample $t$ test result reveled that there is a statistical insignificant difference against rural and urban about a school leaders salary to participate in school leaders developmentlattracts potential candidates involving in school leadership development since the $p>0.05(p=0.848, \mathrm{t}=-0.202)$. This shows the commitment of school leaders to participate in school leadership development is low because different pressure and tension not attracts potential candidates involving in school leadership development.

The mean value of the opinions of the participants Table 6 of item 4 were calculated and found to be low; that is 2.23 at standard deviation of 1.159 , which is above the average mean value, 3 . The sample $t$ test value results revealed that there is statistical insignificant difference against rural and urban on implementations of recruitment of school leaders has impact on school leadership development Since the $p$-value greater that $p>0.05(p=0.409, \mathrm{t}=-0.836)$. From the above result can conclude that school leadership is not an attractive profession, for which many teachers are didn't applying for the position.

The arithmetic mean value of the opinions of the participants Table 6 items 5 were calculated and found to be low; that is 2.42 at standard deviation of 1.17 which is below the average mean value, 3 , showing that serving as a school leader less motivates school leaders for involving in school leadership development. The independent sample t-test value indicated that though there were mean differences between the two groups of respondents, statistically insignificant difference in advantage of school leadership development for school leaders in the item to create a good working culture in the school because the $p$-value greater than $0.05(p=-0.671, \mathrm{t}=-0.425)$. This indicates that Serving as a school leader de-motivate school leaders for involving in school leadership development. 


\section{Conclusion and Recommendations}

\subsection{Conclusion}

The major purpose of this study is to assess school leadership development process and its implementations in public secondary schools of Bale zone setting. The author employed descriptive survey design to assess the ongoing status and the future prospect SLD process, and its implementations. In the quantitative method, the author employed questionnaire that has been develop by reviewed different sources related to school leadership development process and its implementations.

Regarding to selection of school leaders for leadership development and to the positions in the zone was biased with different issues. Most secondary schools not selected by giving priority for potential candidate pulling to the position and for development but by apolitical royalty and intimacy were the influence.

School leaders' recruitment and leadership development in the zone were not implemented. The criteria for leadership development recruitment are not implemented accordingly with different challenges of external and internal factors.

Assignment of school leaders in zone have some draw backs priority given to assign developed school leaders to the position were few in number in other wards the assignment of school leaders the result of finding shows political interference eroded the profession by lacks of un developed school leaders assigned to the position without regardless of teaching experiences. Majority of respondents disagree with practicality of school leadership development implementations as intended in the guide line of leadership development documents.

School leadership and professionalism are highly related. Mathibe (2005) notes that in South Africa, unlike in the UK and USA, any school leaders can be appointed to the office of school leadership nevertheless of the fact that he/she had a school leadership qualification.

As the findings reveals in most cases during selection, recruitment and assignment of school leaders for leadership development were political affiliated. In case of this potential candidate those apply for leadership development and positions were decreased year to year. Those developed with leadership profession leave the position by different external and internal challenges and forced to teach below their standard.

The commitment of school leaders to participate in school leadership development is low because different pressure and tension not attracts potential candidates involving in school leadership development. Less motivation to participate in school leadership development has side effects in implementations of school leadership development to gain essential skills in leadership profession.

\subsection{Recommendations}

Based on the findings of the study, it is recommended that Zone, Woreda education office and other concerned stakeholders shall provide and implement school leadership development seminars, conferences, coaching, workshops (in-service 
and pre-service) by inventorying skill gaps for newly assigned school leaders without sufficient development in school leadership.

Woreda Education offices and concerned stakeholders had to select, recruit and assigning school leaders prioritize leadership development by identified, and clear and unbiased criteria free of political affiliation and intimacy. Thus, the Bale zone education Bureau and Woredas education office shall use clear unbiased criteria and merit based of school leadership development selection, recruitment and assignment for leadership development and position of leadership.

School leaders had better show commitment and motivation to involve in school leadership development in different strategies as the Zone and Woredas Education office provide leadership development.

The most important action should have to be taken at Woredas and Zone education office is clear understanding on the professionalism of school leadership at all levels as per MoE blue print which stated school leadership is a profession that involves leadership development for leadership position.

\section{Conflicts of Interest}

The authors declare no conflicts of interest regarding the publication of this paper.

\section{References}

Abebe, H., Ketema, B., Kassahun, M., \& Tadese, R. (2009). Practices and Challenges of Enhancing School Leadership in Gambella Regional State. Ethiopian. Journal of Education and Social Sciences, 9, 107-132.

Avolio, B. J. (2004). Leadership Development in Balance: Made/Born. Psychology Press. https://doi.org/10.4324/9781410611819

Avolio, B., \& Gardner, W. (2005). Authentic Leadership Development: Getting to the Root of Positive Elsevier Inc Forms of Leadership. The Leadership Quarterly, 16, 315-338. https://doi.org/10.1016/j.leaqua.2005.03.001 https://www.sciencedirect.com

Avolio, B., Avey, J., \& Quisenberry, D. (2010). Estimating Return on Leadership Development Investment. The Leadership Quarterly, 21, 633-644. https://doi.org/10.1016/j.leaqua.2010.06.006

Barber, M., Whelan, F., \& Clark, M. (2010). Capturing the Leadership Premium: How the Worlds to School Systems Are Building Leadership Capacity for the Future. Report of Mckinsey and Company.

http://www.mckinsey.com/clientservice/SocialSector/ourpractices/

Best, J. W., \& Kahn, J. R. (2003). Research in Education (9th Edition). Prentice Hall of Inc. Private Limited.

Bolden, R. (Ed.) (2006). Leadership Development in Context. Leadership South West Research Report No. 3. Centre for Leadership Studies, University of Exeter.

Bush, T. (2009). Leadership Development and School Improvement: Contemporary Issues in Leadership Development. Educational Review, 61, 375-389.

https://doi.org/10.1080/00131910903403956

Bush, T., \& Jackson, D. (2002). A Preparation for School Leadership: International Pers- 
pectives. Educational Management Administration \& Leadership, 30, 417-429. https://doi.org/10.1177\%2F0263211X020304004

Bush, T., \& Oduro, G. (2006). New Principals in Africa: Preparation, Induction and Practice. Journal of Education Administration, 44, 359-375. https://doi.org/10.1108/09578230610676587

Bush, T., Kiggundu, E., \& Moorosi, P. (2011). Preparing New Principals in South Africa: the ACE: School Leadership Program. South African Journal of Education, 31, 31-43. https://doi.org/10.15700/saje.v31n1a356 http://wrap.warwick.ac.uk/37562/

Cohen, L., Manion, L., \& Morrison, K. (2007). Research Methods in Education (6th ed.). Routledge. https://doi.org/10.4324/9780203029053

Collins, D. (2002). The Effectiveness of Managerial Leadership Development Programs: A Meta-Analysis of Studies from 1982-2001. PhD Thesis, Louisiana State University.

D’Arbon, T., Duigan, P., Duncan, D., \& Goodwin, K. (2001). Planning for the Future Leadership of Catholic Schools in New South Wales. Paper for British Educational Research Association Annual Conference, Leeds, 13-15 September 2001.

Day, D. (2001) Leadership Development: A Review in Context. Leadership Quarterly, 11, 581-613. https://doi.org/10.1016/S1048-9843(00)00061-8

Etsegenet, S. (2019). Management Development Practices and Challenges in Government Secondary Schools in Yeka Sub City. MA Thesis, Addis Ababa University.

Fink, D. (2005). Developing Leaders for Their Future Not Our Past. In M. J. Coles, \& G. Southworth (Eds.), Developing Leadership: Creating the Schools of Tomorrow. Open University Press McGraw Hill House.

Gay, L., Geoffrey, E., \& Airasian, P. (2012). Educational Research: Competencies for Analysis and Application (10th ed.). Pearson.

Hallinger, P., \& Bryant, D. (2012). Mapping the Terrain of Educational Leadership and Management in East Asia. Journal of Educational Administration, 51, 618-637. https://doi.org/10.1108/JEA-05-2012-0066

Hoy, W. K., \& Miskel, C. G. (2005). Educational Administration, Theory, Research and Practice (7th Edition). McGraw-Hill. School Leadership \& Management, 32, 453-471.

Mathibe, I. R. (2005). A Beehive Model for Management and Leadership Development in Primary Schools in North West Province, South Africa. PhD Thesis. North West University.

MoE (1994). Federal Democratic Republic Government of Ethiopia Education and Training Policy. Ministry of Education.

MoE (2007). Ethiopian Teacher's Development Programme Guideline. Ministry of Education, Ethiopia, Directorate Addis Ababa.

MoE (2008). General Education Quality Improvement Package (GEQIP). Ethiopian Federal Ministry of Education.

MoE (2010). Education Sector Development ESDP IV: Program Action Plan Addis Ababa. EMPDA.

MoE (2013). National Professional Standard for School Principals. Ministry of Education Ethiopia.

MoE (2014). National Curriculum Framework for MA Degree in School Leadership Ministry of Education. Teachers and Education Leaders Development Directorate Final Document June, 2014.

MoE (2019). Ethiopian Education Development Roadmap (2018-30). Ministry of Educa- 
tion Ethiopia.

Mugenda, O. M., \& Mugenda, A. G. (2003). Research Methods: Quantitative and Qualitative. Approaches. African Centre for Technology Studies.

Tesfaye, G. (2018). Development of the Ethiopian School Leadership: Foundation, SelfDependence, and Historical Erratic Evolution. Journal of Educational Administration and History, 50, 343-363. https://doi.org/10.1080/00220620.2018.1512956

Tesfaye, G. (2019). Primary School Principals in Ethiopia: Selection and Preparation. Educational Management Administration and Leadership, 48, 651-681.

https://doi.org/10.1177\%2F1741143219836673

TGE (1994). Education and Training Policy. EMPDA.

Williams, T. (2001). The Unseen Exodus: Meeting the Challenges of Replacing Ontario's Principals and Vice-Principals. O.P.C. Register, 3, 10-14.

Workineh, A. (2012). School Management and Decision Making in Ethiopian Government Schools. Young Lives. 